DOI: 10.35774/app2021.01.100

\section{Вячеслав Тєнєшев,}

викладач кафедри міжнародного права $i$

міграиійної політики Західноукраїнського

наиіонального університепу

\section{Bima Komuc,}

студентка юридичного факультету

Західноукраїнського наиіонального

університету

\section{ВИКРАДЕННЯ ДИТИНИ ОДНИМ ІЗ БАТЬКІВ, ПРОБЛЕМИ}

\section{КВАЛІФІКАЦІЇ ЗЛОЧИНУ ТА ВІДПОВІДАЛЬНІСТЬ ЗА ТАКІ ДІЇ}

У статті досліджено прогалини у законодавстві Україн щодо кваліфікаиії злочину викрадення дитини одним із батьків та виконання судового рімення про вилучення дитини у разі їївідмови повертатися у закони балансу інтересів між батьками щодо місия прожсивання спільної дитини. Проаналізовано досвід зарубі жсии

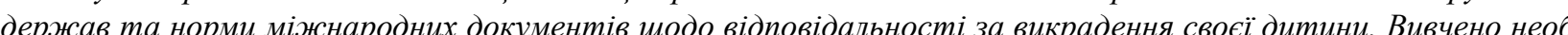
хідність законодавчого врегулювання даної проблеми та висвітлено наслідки ії ігнорувания.

Ключові слова: викрадення дитини одни із батьків, прочедура вилучения дитини законне місче проживання дитини, сімейне право.

\section{Тенешев В., Котис В.}

Похищение ребенка одним из родителей, проблемы квалификации преступления и ответственность за такие действия

В статье исследованы пробель в законодательстве Украины относительно квалификаиии преступле ния похищение ребенка одния из родителей и выполнения судебного решения об изъятии ребенка в случае его отказа возвращаться в законное место жительства. Выделены возможные средства для предотвращени и эффективного реагирования на случаи нарушения баланса интересов между родителями о месте жительства общего ребенка. Проанализирован опыт зарубежных государств и нормы международных документов об ответственности за похищение своего ребенка. Изучено необходимость законодательного урегулирования данной проблемы и освещены последствия ее игнорирование.

Ключевые слова: похищение ребенка одним из родителей, прочедура изъятия ребенка, законное место жительства ребенка, семейное право.

Tienieshev V., Kotys V. actions

Abduction of a child by one looking for parents, problems of qualifying a crime and responsibility for such

The article examines the gaps in the legislation of Ukraine regarding the qualification of the crime of abduction of a child by one of the parents and the execution of a court decision on the removal of a child in case of his refusal to return to his legal place of residence. Possible means for prevention and effective response to cases of imbalance of interests between parents regarding the place of residence of a joint child are identified. The experience of foreign states and the norms of international documents on responsibility for the abduction of a child are analyzed. The necessity of legislative regulation of this problem is studied and the consequences of ignoring it are covered.

In Ukraine there is no culture of civilized divorce and joint custody, it often comes to upsetting the balance of interests between parents, they take a selfish position, in which the child suffers primarily, which becomes a «bargaining chip» and a means of mutual parental revenge. Ignoring the need for a clear and effective legal solution to this issue leads to a decrease in the birth rate, and as a consequence, to the aging of the Ukrainian nation. family law.

Keywords: abduction of a child by one of the parents, procedure of child removal, legal residence of the child,

\section{О Вячеслав Тєнешев, Віта Котис, 2021}

Постановка проблеми. В Україні дуже часто і гостро постає проблема досягнення згоди між батьками щодо місця проживання дитини та способу спілкування з нею після розлучення (як формального, так i юридично визнаного), що проявляється через перешкоджання чи повну заборону спілкування 3 дитиною та навіть їі викрадення чи переховування одним із батьків.

Згідно зі статистичними даними кількість звернень щодо порушення права на опіку з кожним роюм зростає. Так, якщо у 2019 році таких позовів налічувалось близько 900 , то вже у 2020 - понад 1500 - це приблизно 6 звернень кожного робочого дня. Незважаючи на таке швидке поширення проблеми, держава досі не має ефективних важелів впливу на цю ситуацію, через що винні особи залишаються непокараними. Враховуючи те, що в Україні загалом відсутня культура цивілізованих розлучень та спільної опіки, то часто справа доходить до порушення балансу інтересів між батьками, вони займають егоїстичну позицію, в якій, насамперед, страждає саме дитина, яка стає «розмінною монетою» та засобом обопільної батьківсько помсти. Ігнорування необхідності чіткого та дієвого правового вирішення цього питання призводить до зниження коефіцієнту народжуваності i, як наслідок, до старіння української нації

Аналіз останніх досліджень і публікацій. Дана проблема досі є малодослідженою, проте надзичайно важливою та актуальною. Багато українських науковців, таких як Кабанов В., Тріпульський Г Євтушенко О., досліджують тему міжнародного викрадення дітей, проте мало хто вивчає проблему кваліфікації злочину стосовно викрадення дитини одним із батьків на території України та проблему виконання постанов суду щодо вилучення дитини.

Метою статті $є$ дослідження прогалин у законодавстві України щодо порушення права на опіку одного із батьків та можливих засобів для запобігання такому явищу й дієвого реагування на випадки викрадення дитини одним із батьків, аналіз норм міжнародних документів та досвіду зарубіжних країн із цього питання.

Виклад основного матеріалу дослідження. Дитина - це повноправна людина, яка не може бути присвоєна або викрадена. 3 моменту народження і до моменту досягнення повноліття особа має правовий статус дитини (ч. 1 ст. 6 Сімейного кодексу України) [7], а отже, ііі права захишаються Конститушісі

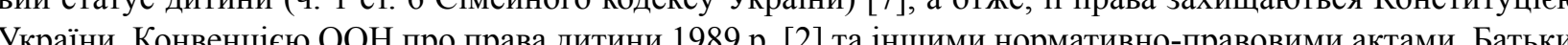
України, Конвенцією ООН про права дияни 1989 р. [2] та іншими нормативно-правовими актами. Батьки, своєю чергою, мають невід ємне

Проте у випалку розлучения батьків (як формального, так і документальо засвідченого) гостро

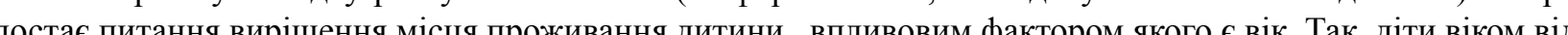

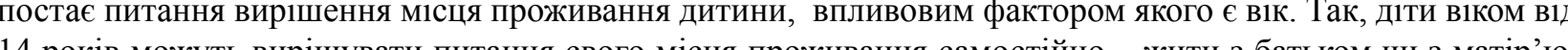
14 років 14 ров вире

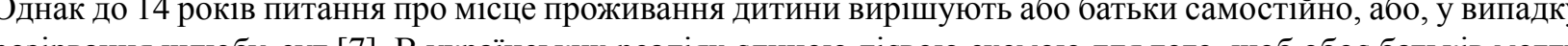

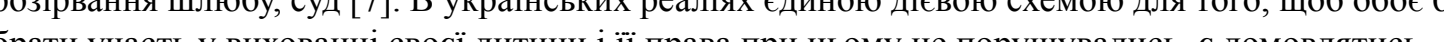
брати участь у вихованні своєї дитини і іїі права при цьому не порушувались, $є$ домовлятись.

В інших державах практика спільної опіки шляхом домовленості, коли дитина почергово живе то в матері, то в батька, $\epsilon$ дуже поширеним явищем, проте в Україні саме через низьку культуру сімейних відносин, що призводить до відсутності згоди між колишнім подружжям, iіi майже не застосовують. Тому найпоширенішим способом вирішення місця проживання малолітньої дитини після розлучення батькі $\epsilon$ саме рішення суду, але в Україні навіть воно не гарантує того, що дитина залишатиметься в законному місці проживання

Прикладом такої проблеми є справа Зоріної Т. ІЇі колишній чоловік викрав спільну малолітню дитину і не повертав їі матері, незважаючи на те, що рішення суду щодо місця проживання було саме на корист жінки. То що ж робити у такій ситуаці1.

Згідно 3 ч. 2 ст. 146 КК України викрадення малолітньої особи є злочином, за яким його суб’єкт повинен нести кримінальну відповідальність [4]. Однак, такого поняття як «викрадення дитини одним батьків» взагалі не існує: викрасти може тільки стороння людина, а батьки хіба що забирають дитину до себе. Тобто за вчинене порушення найближчий родич дитини не нестиме ні адміністративної, ні кримінальної відповідальності. На кваліфікацію злочину щодо викрадення дитини не впливає сімейний стан батьків: чи проживають вони у зареєстрованому шлюбі, чи розлучення цих осіб $є$ юридично визнаним - неважливо

Винятком $є$ лише випадок, коли дитина народилася і виховувалася у формальному (незареєстрованому) шлюбі, а один із подружжя не $\epsilon$ рідним батьком чи матір'ю дитини. Якщо процедура усиновленн батьком чи матір'ю не виконана, зміну місця проживання дитини одним із батьків цілком можна розглядати

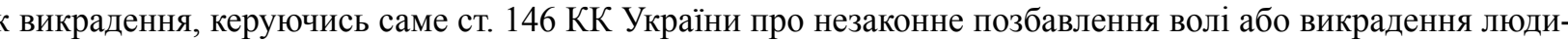
ни.

ISSN 2524-0129 (Print) / ISSN (2664-5718) (Online). Актуальні проблеми правознавства. 1 (25)/2021 
Однак постає питання, що робити у випадку Зоріної Т., коли суб’єктом викрадення дитини є законний батько, що, відповідно, і блокуе ії можливість посилатися на дану статтю?

У випадку викрадення дитини одним із законних батьків можна посилатись лише на ч. 1 ст. 162 Сімейного кодексу України, в якій сказано: «Якщо один з батьків самочинно, без згоди другого з батьків змінить місце проживання дитини, у тому числі способом ії викрадення, суд за позовом заінтересованої особи має право негайно постановити рішення про відібрання дитини і повернення їі за попереднім місцем проживання» [7]. Виключенням із цього правила є дві ситуації, за наявності яких суд не буде приймати рішення про повернення дитини у попереднє місце проживання:

1) якщо залишення іiі за попереднім місцем проживання створюватиме реальну небезпеку для іiі життя та здоров'я

2) якщо обставини змінилися так, що повернення суперечить інтересам дитини (наприклад, особа, 3 якою проживала дитина, померла) [7].

Зоріна Т., посилаючись на дану статтю, подала позов до суду для дозволу виконання процедури вилучення своєї доньки. Суд прийняв рішення про повернення дитини у попереднє місце ії проживання проте, на практиці це рішення суду не було виконано, тому що батько дитини під час вилучення не дав такої можливості.

Згідно з українським законодавством на процедурі вилучення повинні бути присутні державні виконавці, працівники служби у справах дітей, поліція, а також мати (Зоріна Т.), якій і повинні були передати дитину. Проте що робити, коли під час самого вилучення малолітня дитина, схильна до тиску з боку батька, відмовляється йти 3 незнайомими людьми? Саме так і вчинив колишній чоловік Зоріної Т., психологічно тиснучи на свою дитину, яка, злякавшись сторонніх осіб, що прибули для виконання постанови суду про вилучення, відмовилась змінити своє місце проживання. Виконавча служба, навіть маючи потрібну постанову суду, не має права здійснювати будь-який фізичний вплив на дитину, а норми Постанови Кабінету Міністрів України «Порядок провадження органами опіки та піклування діяльності, пов'язаної із захистом прав дитини» від 2008 p. вказують на те, шо дитина не може бути насильно розлучена зі своїми батьками [6]. Згідно з шим нормативн-правовим актом виконавча служба мас право негайно вилучити дитину ми [6]. у зипалках, якщо один із батьі жорстоко поводиться з дитиною, с хронічними аукоголіки або наркомен

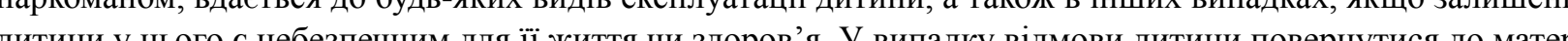
дит. пбастен рб рядку). А поліція у тало на такому вилученні.

Постанова Кабінету Міністрів України «Порядок провадження органами опіки та піклування діяльності, пов'язаної із захистом прав дитини» та Закон України «Про виконавче провадження» не враховують тог, що під иас вилучення малолия особа моне відмовитись повернупися до матері, навіь якщо iii викрадено [6]. Відповідно, порядок дій державних виконавців, працівників служби у справах дітей та поліції в жодному нормативно-правовому акті не встановлено.

Після декількох наступних спроб вилучення виконавчій службі все-таки вдається передати дитину Зоріній Т., проте таких закінчених проваджень на користь заінтересованої особи дуже мало. Протягом 2019 року в Україні на виконанні перебувало 251 подібне рішення, з яких було виконано лише 73 (більшість цих справ були подані до суду ще у 2017 році).

Єдиним механізмом для швидшого вирішення цього питання в Україні $є$ подання заяви на розшук батька та дитини. Чоловік буде змушений прийти на засідання суду разом із викраденою дитиною, щоб довести факт того, що з ними все гаразд. На практиці найчастіше саме тоді і вдається вилучити викрадену дитину в одного із батьків.

Члени Комітету з сімейного права Національної Асоціації Адвокатів України вже подавали сво зауваження й пропозиції до проєкту Закону України «Про внесення змін до деяких законодавчих актів України щодо визначення місця проживання дитини в безспірному порядку» (№ 4154 від 25.09.2020 року), але до сьогодні цей законопроєкт не виносився на засідання Верховної Ради України [9].

Також існують адміністративні важелі впливу за ухилення від виконання рішення суду: якшо той 3 батьків, з ким незаконно проживає дитина, переховується, переїжджає з місця на місце, державний виконавешь може накласти штраф у розмірі 1700 гривень, при повторному невиконанні рішення суду - штра у розмірі 3400 гривень. Однак, сплата штрафів у питаннях батьківства не $\epsilon$ дієвим важелем впливу, адже

дин із батьків, викрадаючи дитину, взагалі не зважає на будь-які покарання. Прикладом $є$ справа Ялузіна Д., дружину якого штрафували таким чином кілька разів, але бачитись із донькою йому це так і не допомогло. Більше того, цих штрафів його колишня дружина не сплачує (iї ім’я ще досі значиться в Єдиному реєстрі боржників Міністерства Юстиції України).

Ще однією проблемою $\epsilon$ некомпетентність виконавчої служби в частині засвідчення факту викрадення дитини одним із батьків. Прикладом цього може слугувати справа № 201/17854/16-ц, у якій потерпі-

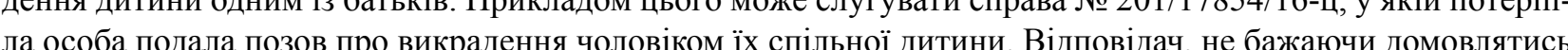
із дружиною про місце прожиранн дитини, виїхав в інше місто. Проте суд вказав на те, шо на час розпляу 13 дружиною про місце проживання дитини, виїхав в інше місто. Проте суд вказав на те, що на час розгляду справи місце проживання дитини не було встановлено органом опіки та піклування, а тому вимога про відібрання на підставі частини 1 статті 162 СК України $є$ передчасною та задоволенню не підлягає.

Незаконне переміщення і неповернення дітей $є$ однією із сучасних проблем, якій присвячена значна кількість міжнародних правових актів, однак усі вони регулюють відносини саме щодо міжнародного викрадення дітей.

Гаазька Конвенція про цивільно-правові аспекти міжнародного викрадення дітей від $25.10 .1980 \mathrm{p}$ створює просту й ефективну процедуру для забезпечення повернення дітей, протиправно вивезених або утримуваних на території іноземної держави, до держави їх постійного місця проживання і передбачає можливість для звернення з двома видами заяв: про повернення дитини та про забезпечення права доступу до дитини [3].

Кількісна статистика розгляду справ судами іноземних держав щодо міжнародного викрадення дітей на основі Гаазької Конвенції 1980 р. впродовж 2006-2020 рр. (рис. 1):

R-ork लक्यs
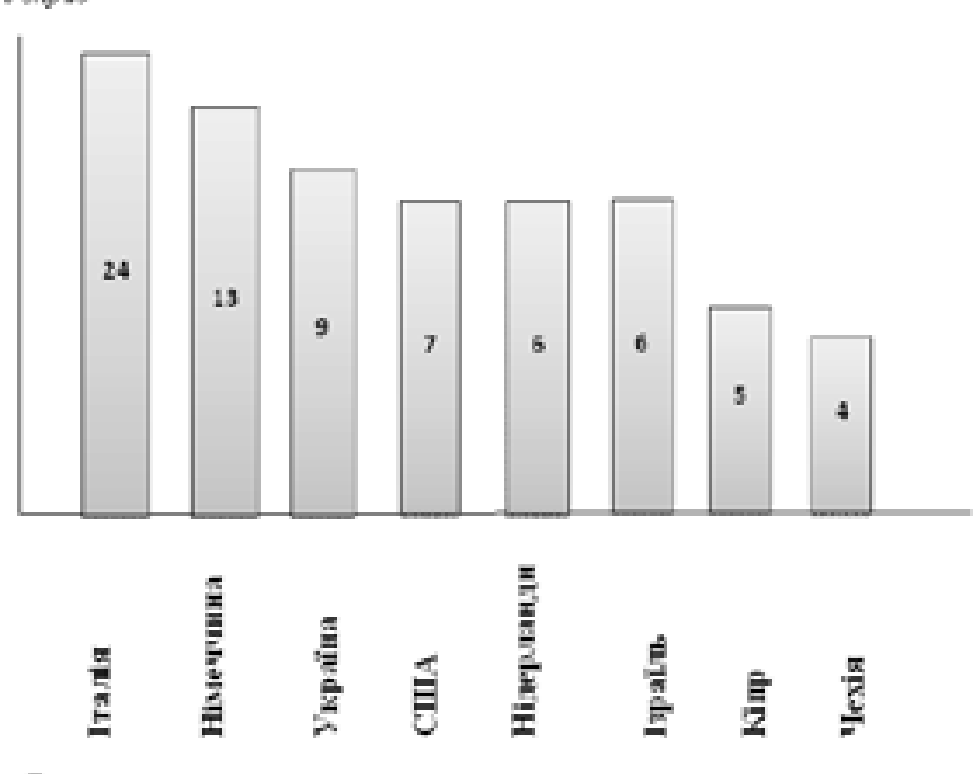

Статистика розгляду справ судами іноземних держав щодо міжнародного викрадення дітей [8]

Проаналізувавши зарубіжний досвід стосовно цього питання, можна зробити висновок, що деякі держави у своє законодавство включають злочин «Викрадення дитини одним із батьків». Зокрема, серед таких є США: 1970 р. такі неправомірні дії на законодавчому рівні визнаються злочином.

Японії вилучення дитини одним із батьків без згоди іншого з батьків кваліфікується як викрадення. За такі дії суб’єкт злочину повинен нести кримінальну відповідальність у вигляді позбавлення волі від 4 місяців до 5 років [10].

У кримінальному законодавстві Франції зазначається: «Викрадення дитини одним із батьків - це ситуація, коли один із батьків утримує дитину, яка повинна бути з іншим із батьків. Те саме стосується ситуацій, коли один із колишнього подружжя переїжджає зі своєю дитиною, не повідомивши своїх нових координат протягом одного місяця». За такі правопорушення винна особа повинна нести кримінальну відповідальність у вигляді позбавлення волі до 4 років або адміністративну відповідальність. 
Висновки. Проаналізувавши проблеми та невідповідності у законодавстві України щодо питання викрадення дитини одним із батьків, пропонуємо наступне.

Виділити в окрему частину в межах ст. 146 КК України новий склад злочину, який повинен стосуватися викрадення дитини одним із батьків.

Посилити кримінальну відповідальність за невиконання судових рішень щодо батьківської відповідальності.

Прийняти закон, який дозволить батькам при розлученні підписувати нотаріально засвідчений договір, який визначатиме, з ким дитина буде проживати, як і коли буде бачитись з іншим із батьків. Та домовленості можуть відбуватися і через медіаторів (посередників). Для того, щоб такий договір був ефективним, потрібно встановлювати невідворотну відповідальність за його недотримання.

У випадку неспроможності самостійного вирішення батьками місця проживання дитини, суду доцільно одночасно вирішувати усі питання батьківської відповідальності, а саме: визначення місця проживання та встановлення графіку спілкування дитини з кожним із батьків.

\section{Список використаних джерел}

1. Валуєва Н. О., Кравчук М. О., Полякова К. А. Питання врахування думки дитини під час вирішення питань, що стосуються її життя. Вісник АМСУ. Серія: «Право». 2015. № 1 (14). С. 91-94.

2. Декларація прав дитини Генеральної Асамблеї ООН від 20.11.1959. URL: https://zakon.rada.gov.ua/ laws/show/995_384\#Text (дата звернення: 19.01.2020)

3. Конвенція про цивільно-правові аспекти міжнародного викрадення дітей від 29.04.2011 p. URL: https:/ zakon.rada.gov.ua/laws/show/995_188\#Text (дата звернення: 19.01.2020)

4. Кримінальний кодекс України: чинне законодавство зі змінами та допов. станом на 30.12.2020р. / відп. за вип. А. В. Паливода. Київ: ПАЛИВОДА, 2019. 264 с.

5. Міжнародна конвенція про захист усіх осіб від насильницьких зникнень. Щодо приеднання до Конвенції із заявами див: Закон № 525-VIII. 17.06.2015. URL: https://zakon.rada.gov.ua/laws/show/995_154\#Text (дата звернення: $19.01 .2020 \mathrm{p}$.)

6. Постанова Кабінету Міністрів України «Порядок провадження органами опіки та піклування діяльності, пов’язаної із захистом прав дитини» від 24 вересня 2008 p. № 866. URL: https://www.kmu.gov.ua/ npas/162001537 (дата звернення: 19.01.2020)

7. Сімейний кодекс України: чинне законодавство зі змінами та допов. станом на 02.12 .2020 p. URL: https://zakon.rada.gov.ua/laws/show/2947-14\#Text (дата зверенення: 19.01.2020)

8. Сніжко М. Б. Досвід виконання Міністерством Юстишії України Конвеншії про цивільно-правові пекти міхнародного викрадення дітей $1980 \mathrm{p}$. та практика розгляду таких справ судами України. URL

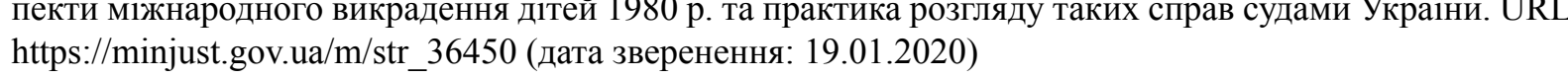

9. Проєкт Закону України «Про внесення змін до деяких законодавчих актів України щодо визначення місця проживання дитини в безспірному порядку» № 4154 від 25.09.2020 p. URL: https://www. kmu.gov.ua/bills/proekt-zakonu-pro-vnesennya-zmin-do-deyakikh-zakonodavchikh-aktiv-ukraini-shchodo-

viznachennya-mistsya-prozhivation

0. Kohm L. M. Tracing the Foundations of the Best Interest of the Child Standard in American Jurisprudence Journal of Law and Family Studies. 2008. Vol. 10, Issue 2. p. 40

\section{References}

1. Valuyeva, N. O., Kravchuk, M. O. \& Polyakova, K. A. (2015). Pytannya povernennya dumky dytyny pid chas vyrishennya pytan, shcho stosuyutsya yii zhyttya [The question of taking into account the views of the child when addressing issues related to his life]. Visnyk AMSU. Seriia: «Pravo»-Bulletin AMSU. Law, 1 (14), 91-94 [in Ukrainian].

2. Deklaratsiya prav dytyny Heneralnoyi Asambleyi OON [Declaration of the Rights of the Child of the UN General Assembly] (20.11.1959). Retrieved from https://zakon.rada.gov.ua/laws/show/995_384\#Text [in Ukrainian].

3. Konventsiya pro tsyvilno-pravovi aspekty mizhnarodnoho vykradennya ditey [Convention on the Civil Aspects of International Child Abduction] (29.04.2011). Retrieved from https://minjust.gov.ua/m/str_28838 [in Ukrainian].

4. Kryminalnyi kodeks Ukraine [Criminal Code Ukraine]. (25.09.2019). Kyiv: vyd-vo PALYVODA [in Ukrainian].
5. Mizhnarodna konventsiva pro zakhyst usikh osib vid nasylnytskykh znyknen [International Convention for the Protection of All Persons from Enforced Disappearance] (17.06.2015). Retrieved from https://zakon.rada. gov.ua/laws/show/995_154\#Text [in Ukrainian].

6. Postanova Kabinetu Ministriv Ukrayiny «Poryadok provadzhennya orhanamy opiky ta pikluvannya diyalnost povyazanoyi iz zakhystom prav dytyny» № 866 [Resolution of the Cabinet of Ministers of Ukraine «Procedure povyazanoyi iz zakhystom prav dytyny» № 866 [Resolution of the Cabinet of Ministers of Ukraine «Procedure for Carrying Out Activiles Related to the Protection of the Rights of the Child by Bodies of Guardianship and

Simeynyy kodeks Ukrayiny: chynne zakonodavstvo zi zminamy ta dopov. [Family Code of Ukraine] (02.12.2020). Retrieved from https://zakon.rada.gov.ua/laws/show/2947-14\#Text [in Ukrainian].
(ame-

Snizhko, M. B. Dosvid vykonannya Ministerstvom Yustytsiyi Ukrayiny Konventsiyi pro tsyvilno-pravov aspekty mizhnarodnoho vykradennya ditey 1980 r. ta praktyka rozhlyadu takykh sprav sudamy Ukrayiny [Experience of implementation by the Ministry of Justice of Ukraine of the Convention on Civil Law Aspect of International Child Abduction of 1980 and the practice of consideration of such cases by the courts of Ukraine]. Retrieved from https://minjust.gov.ua/m/str_36450 [in Ukrainian].

9. Proyekt Zakonu Ukrayiny «Pro vnesennya zmin do deyakykh zakonodavchykh aktiv Ukrayiny shchodo vyznachennya mistsya prozhyvannya dytyny v bezspirnomu poryadku» № 4154 [Draft Law of Ukraine «On Amendments to Certain Legislative Acts of Ukraine Concerning the Determination of the Place of Residence of a Child in an Indisputable Order»] (25.09.2020). Retrieved from https://www.kmu.gov.ua/bills/proektzakonu-pro-vnesennya-zmin-do-deyakikh-zakonodavchikh-aktiv-ukraini-shchodo-viznachennya-mistsyaprozhivannya-ditini-v-bezspirnomu-poryadku [in Ukrainian].

10. Kohm, L. M. (2008). Tracing the Foundations of the Best Interest of the Child Standard in American Jurisprudence. Journal of Law and Family Studies, 10 (2), 40 [in English].

Стаття надійшла до редакції 27.02.2021. 